\title{
The Effect of Cooperative Learning on Students Science Process Skill
}

\author{
Yuyun Mahrani \\ Postgraduate Student, Department of Science Education \\ Universitas Negeri Medan \\ Medan, Indonesia \\ yuyun.mahrani@yahoo.co.id
}

\author{
Retno Dwi Suyanti \\ Department of Chemistry \\ Universitas Negeri Medan \\ Medan, Indonesia
}

\author{
R. Mursid \\ Department of Science Education \\ Universitas Negeri Medan \\ Medan, Indonesia
}

\begin{abstract}
This study aim to determine the effect of Cooperative Learning model on students science process skills at water cycle topic in grade 5 elementary school 060818 Medan. The research applied experimental method with 2 classes are chosen by using random sampling technique. The class $5 \mathrm{~A}$, which consists of 34 students, is taught by using Cooperative Learning Talking Stick Type and the class $5 \mathrm{~B}$, which consists of 35 students, is taught by using Cooperative Learning Picture and Picture Type. The research instruments are essay tests which the validity, reliability and the level of difficulty have been tested. The data are analyzed by using two ways Analysis of Variance (Anava). The results showed science process skills of students who are learning using cooperative learning Picture and Picture Type are higher than the students who are learning using cooperative learning Talking Stick Type.
\end{abstract}

\section{Keywords-Cooperative Learning; Science Process Skills)}

\section{INTRODUCTION}

The teacher plays an important role in the learning process. The learning process is said to be successful when the teacher performs the learning process effectively. The learning process is said to be effective if students are actively involved, both mentally, physically, and socially [1]. To involve students actively in learning, the teacher must make students as the learning center (student-centered). Therefore, the role of teachers in the overall learning in school is very important. Teachers as learning managers need to have high creativity in managing the learning process. Creativity in managing the learning process is also needed to create a conducive and enjoyable atmosphere in learning, including in learning Sciences.

The teacher-centered learning process results in a lack of understanding of students in learning Sciences. This is proven by student learning outcomes obtained by researcher when conducting observation. Mid semester test results for the 2017-2018 school year class 5-1 shows that the grade point average is 60.83 with the highest score of 80 and the lowest value is 35 . The learning outcomes clearly prove that there are problems with science learning at elementary school 060818.

To overcome this problem, the science learning in elementary school needs to be changed its orientation, from teacher-centered learning to student-centered learning. Learning is designed to teach students, which means the learning system places students as the subjects of learning [2]. One alternative solution that can change the learning orientation and also at the same time able to overcome the above problem is by implementing a collaborative learning model.

Cooperative learning is a learning model where students learn and work in small groups collaboratively with 5 members with heterogeneous group structures [3]. Cooperative learning is a way of approach or a series of strategies specifically designed to encourage students to work during the learning process. Cooperative learning models place students as subjects of learning (student-oriented) so that the learning atmosphere develops democratically and students have the opportunity to develop their potential [4]

Process skills can be interpreted as an insight or role model for the development of intellectual, social, and physical skills derived from fundamental abilities that in principle already exist in students [5]. Science process skills are skills that originate from fundamental abilities which include observing, classifying, predicting, hypothesizing, measuring, research planning, controlling variables, interpreting, implementing, concluding and communicating [6].

The skills or abilities and attitudes of the science process are very important, because it can make a person have high flexibility in dealing with changes around him, including in relationships, at work, or in an institution or organization. Empowerment of science process skills needs to be done in the science learning process, this is because if students have mastered the indicators of science process skills, students will 
find it easier to learn the science by constructing their own knowledge and experience [7].

Science Process skills involve cognitive or intellectual, manual and social skills. Cognitive or intellectual skills are involved because by doing the science process skills students use their minds. Manual skills are clearly involved in process skills because they use tools and materials, measurement, preparation or assembly of tools. With social skills intended that students interact with each other in carrying out teaching and learning activities with process skills, for example discussing observations [8].

Process skills are a strategic learning approach, utilizing all the power (functions) of students themselves, are generic (supporting added value and enhancing creativity), intact goals and humanity, simultaneously enhancing students selfsocialization [9]. Science process skills provide students with a proper understanding of science [10]. Students can experience scientific stimuli and can better understand the facts and concepts of science. Teaching with process skills means giving students opportunities to work with science, not just telling or listening to stories about science. On the other hand, students feel happy because they are active and do not become passive learners. Using Science Process Skills make students learn the process and products of science at once.

Science process skills have an important role in finding scientific concepts. The concept is one of the initial knowledge that must be possessed by students because the concept is the basis in formulating the principle meaning that enable students to master the principles and theories that must be mastered first. Through learning using science process skills, students understanding and mastery of the science concepts will be better.

The indicator of student activities in each stage of science process skills are [11] Observation, the indicator is to use as much senses as possible, collecting/using relevant facts; 2) Classification, the indicator is to record each observation separately, look for differences/equations, contrast characteristics, compare, look for the basis of grouping or classification, linking observations; 3) Interpretation, the indicator is connecting observations, finding patterns in a series of observation, concluding; 4) Predict, the indicator is to use the patterns of observations, express what might happen in circumstances that have not been observed; 5) Asking questions, the indicator is asking what, how and why, ask for an explanation, asking a question with a hypothesis background.

6) Hypothetically, the indicator is knowing that there is more than one possible explanation of an event, realizing that an explanation needs to be tested for truth by obtaining more evidence or doing a problem-solving method; 7) Planning an experiment/research, the indicator is determining the tools/materials/sources to be used, determining certain variables/factors, determining what is measured, observed, recorded, determining what will be implemented in the form of work steps; 8) Using tools/materials, the indicator is using tools/materials, knowing the reasons why using tools/materials, knowing how to use tools/material.
9) Applying the concept, the indicator is to use concepts that have been learned in new situations, using concepts in new experiences to explain what is happening; 10) Communicating, the indicator is changing the form of presentation, giving/describing empirical data from the results of experiments or observations with charts or table charts, compiling and submitting a systematic report, explaining the results of experiments or research, reading graphs or tables or diagrams, discussing the results of a problem or an event, and; 11) Carry out experiments/experimenting.

Learning model is a plan or pattern that can be used to shape the curriculum, design learning material, and guide learning in the classroom or otherwise [12]. This means that the learning model is a reference used to design learning starting from the plan, materials and the implementation process. There are many learning models, such as direct learning models, cooperative learning, problem based learning, discussion and strategy learning. In this study the researcher only focuses on cooperative learning models.

Cooperative learning is a learning model where students learn and work in small groups collaboratively with 5 members with heterogeneous group structure [13]. Cooperative learning is a way of approach or set of strategies specifically designed to encourage students to work together during the learning process.

Cooperative learning refers to various types of learning models in which students work together in small groups consisting of various levels of achievement, gender, and different ethnic backgrounds to help each other in learning the subject matter. In cooperative classes, students are expected to be able to help each other, discuss each other, and argue to the knowledge they master at that time and close the gap in their respective understandings. Cooperative learning is more than just group learning because in this learning model there must be a cooperative encouragement and task structure that allows open interaction and relationships that are effective independence between group members.

Of the several definitions put forward by the experts above, it can be concluded that cooperative learning is a learning model that places students in small groups whose members are heterogeneous, consisting of students with high, medium, and low achievement, women and men with different ethnic backgrounds to help each other and work together to study subject matter so that all members learn optimally.

Learning with the Talking Stick model can encourage students to be brave in expressing opinions. Talking stick learning is a learning used by the teacher in achieving the desired learning goals. Talking stick as intended by this study, in the teaching and learning process in the classroom is oriented to the creation of learning conditions through stick games given from one student to another when the teacher explains the subject matter and then asks questions. When the teacher finishes asking questions, the student holding the stick gets the opportunity to answer the question. This is done so that all students have the opportunity to get a turn to answer questions posed by the teacher. Besides talking stick model, this study also applies picture and picture model. 
Picture and picture is a learning strategy that uses images as learning media. These pictures are the main tools in the learning process. Images given to students must be sorted or paired logically. Before the learning process takes place, the teacher has prepared an image that will be displayed either in the form of a card or in the form of a large size chart.

\section{RESEARCH METHODS}

This research is conducted at Public Elementary School 060818 Medan. The population in this study are all grade $5^{\text {th }}$ students in 2017-2018 academic year. The population in this study is 69 students consisting of two classes, namely 5A and $5 \mathrm{~B}$ class. The sample in this study are students of $5 \mathrm{~A}$ class which consists of 34 students and 5B class which consists of 35 students. The sampling technique used is cluster random sampling.

The design of this study is Quasi Experiment by applying the treatment of cooperative learning model type Picture and Picture in the experimental group and cooperative learning model type Talking Stick in the control group. At the end of the experimental activity, the two groups are tested with the same instrument.

TABLE 1. Research Design

\begin{tabular}{|c|c|c|}
\hline Pretest & Treatment & Posttest \\
\hline $\mathrm{X} 1$ & T1 (Picture and Picture) & Y1 \\
\hline $\mathrm{X} 2$ & T2 (Talking Stick) & Y2 \\
\hline
\end{tabular}

Notes:

$\mathrm{X} 1$ : Pretest of experimental group before the treatment is given

$\mathrm{X} 2$ : Pretest of control group before the treatment is given

T1 : Treatment with picture and picture model

T2 : Treatment with talking stick model

Y1 : Posttest of experimental group after the treatment is given $\mathrm{Y} 2$ : Posttest of control group after the treatment is given

The instrument used in data collection is learning outcome tests. The tests are used to measure the science process skills of students. Before the tests are used, it is tested first for validity and reliability by expert validators in order to meet the criteria of good and reliable.

\section{RESULT AND DISCUSSION}

The data in this study is obtained from the learning outcome tests given to students. 5A class is taught by using cooperative learning model type Picture and Picture and 5B class is taught by using cooperative learning model type Talking Stick. The results are analyzed by using SPSS 20 software for windows.

The results of science process skills of students from each class can be seen as follow.
TABLE 2. Pre-Test Result

\begin{tabular}{|c|c|c|c|c|}
\hline \multirow{2}{*}{ No. } & \multicolumn{2}{|c|}{$\begin{array}{c}\text { Picture and Picture } \\
\text { (experimental group) }\end{array}$} & \multicolumn{2}{c|}{$\begin{array}{c}\text { Talking Stick } \\
\text { (control group) }\end{array}$} \\
\cline { 2 - 5 } & Score & frequency & Score & $\begin{array}{c}\text { Frequen } \\
\text { cy }\end{array}$ \\
\hline 1. & 68 & 1 & 70 & 3 \\
\hline 2. & 66 & 2 & 68 & 3 \\
\hline 3. & 64 & 1 & 64 & 2 \\
\hline 4. & 62 & 4 & 62 & 4 \\
\hline 5. & 60 & 2 & 60 & 1 \\
\hline 6. & 58 & 2 & 58 & 1 \\
\hline 7. & 56 & 2 & 56 & 1 \\
\hline 8. & 54 & 4 & 54 & 1 \\
\hline 9. & 56 & 2 & 52 & 7 \\
\hline 10. & 50 & 3 & 50 & 2 \\
\hline 11. & 48 & 1 & 48 & 1 \\
\hline 12. & 46 & 3 & 46 & 4 \\
\hline 13. & 44 & 2 & 44 & 1 \\
\hline 14. & 40 & 1 & 42 & 1 \\
\hline 15. & 38 & 2 & 38 & 1 \\
\hline 16. & 36 & 1 & 36 & 1 \\
\hline 17. & 34 & 1 & 34 & 1 \\
\hline Total & 2330 & 34 & 2318 & 35 \\
\hline Average & & 68,52 & & 66,22 \\
\hline & & & & \\
\hline
\end{tabular}

As can be seen from table 2 above, it is clear that there is no significant difference of score between experimental and control group. In order to know the science process skills of students before the treatment given, the pre-test results are analyzed by using descriptive statistic as can be seen in the following table.

TABLE 3. Description Of Pre-Test Result

\begin{tabular}{|c|c|c|c|c|c|c|c|}
\hline & $\mathrm{N}$ & $\begin{array}{c}\text { The } \\
\text { lowest } \\
\text { score }\end{array}$ & $\begin{array}{c}\text { The } \\
\text { highest } \\
\text { score }\end{array}$ & Total & $\begin{array}{c}\text { Aver } \\
\text { age }\end{array}$ & $\begin{array}{c}\text { Deviation } \\
\text { standard }\end{array}$ & Varians \\
\hline $\begin{array}{c}\text { Experi } \\
\text { mental } \\
\text { group }\end{array}$ & 34 & 34 & 68 & 2330 & 68,52 & 8.223 & 67.626 \\
\hline $\begin{array}{c}\text { Contro } \\
\text { 1 group }\end{array}$ & 35 & 34 & 70 & 2318 & 66,22 & 8.626 & 74.408 \\
\hline
\end{tabular}

Based on table 3 above, it can be seen that the average score of experimental $(68,52)$ and control group $(66,22)$ are relatively the same. After the results of pre-test for both groups have been obtained, the treatment is given. The experimental group is taught by using Picture and Picture model. While the control group is taught by using Talking Stick model. The post-test results of both groups can be seen as the following table. 
TABLE 4. Post-Test Result

\begin{tabular}{|c|c|c|c|c|}
\hline \multirow{2}{*}{ No. } & \multicolumn{2}{|c|}{ Picture and Picture } & \multicolumn{2}{c|}{ Talking Stick } \\
\cline { 2 - 5 } & Score & $\begin{array}{c}\text { Frequenc } \\
\text { y }\end{array}$ & Score & Frequency \\
\hline 1. & 90 & 2 & 84 & 1 \\
\hline 2. & 86 & 2 & 82 & 1 \\
\hline 3. & 84 & 3 & 80 & 1 \\
\hline 4. & 82 & 1 & 78 & 5 \\
\hline 5. & 80 & 3 & 76 & 2 \\
\hline 6. & 78 & 4 & 74 & 4 \\
\hline 7. & 76 & 3 & 72 & 5 \\
\hline 8. & 74 & 3 & 70 & 2 \\
\hline 9. & 72 & 3 & 68 & 3 \\
\hline 10. & 70 & 3 & 66 & 4 \\
\hline 11. & 68 & 5 & 64 & 3 \\
\hline 12. & - & - & 58 & 2 \\
\hline 13. & - & - & 56 & 2 \\
\hline $\begin{array}{c}\text { Tot } \\
\text { al }\end{array}$ & 3444 & 34 & 3092 & 35 \\
\hline $\begin{array}{c}\text { Av } \\
\text { era } \\
\text { ge }\end{array}$ & \multicolumn{2}{|c|}{101.29} & & \\
\hline
\end{tabular}

Based on table 4 above, it can be seen that the average score of experimental groups is higher than the average score of control groups. It can be stated that the average score of both experimental and control group are significantly different.

TABLE 5. Description Of Post-Test Result

\begin{tabular}{|c|c|c|c|c|c|c|c|}
\hline & $\mathrm{N}$ & $\begin{array}{c}\text { The } \\
\text { lowest } \\
\text { score }\end{array}$ & $\begin{array}{c}\text { The } \\
\text { highest } \\
\text { score }\end{array}$ & Total & $\begin{array}{c}\text { Averag } \\
\mathrm{e}\end{array}$ & $\begin{array}{c}\text { Deviatio } \\
\mathrm{n} \\
\text { standard }\end{array}$ & $\begin{array}{c}\text { vari } \\
\text { ans }\end{array}$ \\
\hline $\begin{array}{c}\text { Experi } \\
\text { mental } \\
\text { group }\end{array}$ & 34 & 68 & 90 & 3444 & 101,29 & 6.063 & $\begin{array}{c}36 . \\
761\end{array}$ \\
\hline $\begin{array}{c}\text { Control } \\
\text { group }\end{array}$ & 35 & 56 & 84 & 3092 & 88.34 & 3.577 & $\begin{array}{c}57 . \\
412\end{array}$ \\
\hline
\end{tabular}

The lowest score of experimental group is 68 and the highest score is 90 . While, the lowest score of control group is 56 and the highest score is 84 . It can be seen that there is significant difference between the experimental group which is taught by picture and picture model and the control group which is taught by using talking stick model.

\section{CONCLUSION}

Cooperative learning model gives effect on science process skills of students. Based on the data obtained and analyzed in this study, it can be concluded that the science process skills of students taught by cooperative learning model type picture and picture are higher than the science process skills of students taught by using cooperative learning type talking stick. It is suggested that teachers use cooperative learning in the classroom to improve the science process skills of students.

\section{ACKNOWLEDGMENT}

This study is based on the researcher study which is conducted in public elementary school 060818 Medan. The researcher gratefully thank all the people who have contributed in this study.

\section{REFERENCES}

[1] A. Susanto, "Teori Belajar dan Pembelajaran di Sekolah Dasar". Jakarta: Kencana, 2013

[2] R.D. Suyanti, "Strategi Pembelajarn Kimia". Yogyakarta: Graha Ilmu, 2010

[3] Isjoni, "Pembelajaran Kooperatif: Meningkatkan Kecerdasan Komunikasi Peserta Didik”. Yogyakarta:Pustaka Pelajar, 2009.

[4] Rusman, "Belajar dan Pembelajaran Berbasis Komputer: Mengembangkan Profesionalisme Abad 21". Bandung: Alfabeta, 2012.

[5] I. Kurniasih, "Ragam Pengembangan Model Pembelajaran". Yogyakarta: Kata Pena, 2016.

[6] Istarani, "58 Model Pembelajaran Inovatif. Medan: Media Persada", 2012 .

[7] S. Oktaviani, "Pengaruh Model Pembelajaran Kooperatif Tipe Picture and Picture Terhadap Hasil Belajar IPS Siswa Kelas V SD N 6 Gedong Air Bandar Lampung”. Jurnal Guru Sekolah Dasar Bandar Lampung, 2(2), 2017.

[8] P. Tari, "Pengembangan Model Pembelajaran Kolaboratif Melalui Pendekatan CSCL (Computer Supported Collaborative Learning)". Jurnal Media Komunikasi Pendidikan Teknologi dan Kejuruan, 3(2), 2016

[9] N.P. Samiasih, "Pengaruh Model Pembelajaran Talking Stick Berbantuan Video Pembelajaran Terhadap Hasil Belajar Bahasa Indonesia Kelas VIII". e-Journal Edutech Universitas Pendidikan Ganesha Jurusan Teknologi Pendidikan, 3(1), 2015

[10] M. Tawil, "Keterampilan-keterampilan Sains dan Implementasinya dalam Pembelejaran IPA". Makassar: UNM, 2014

[11] A. Nuryani, "Model Pembelajaran Kooperatif'. Departemen Pendidikan Nasional Direktorat Jenderal Pendidikan Tinggi Direktorat Ketenagaan, 2006 .

[12] Joyce and Weil, "Models of Teaching: Edisi ke delapan". Yogyakarta: Pustaka Belajar.

[13] Isjoni, "Pembelajaran Kooperatif: Meningkatkan Kecerdasan Komunikasi Peserta Didik". Yogyakarta:Pustaka Pelajar, 2009. 